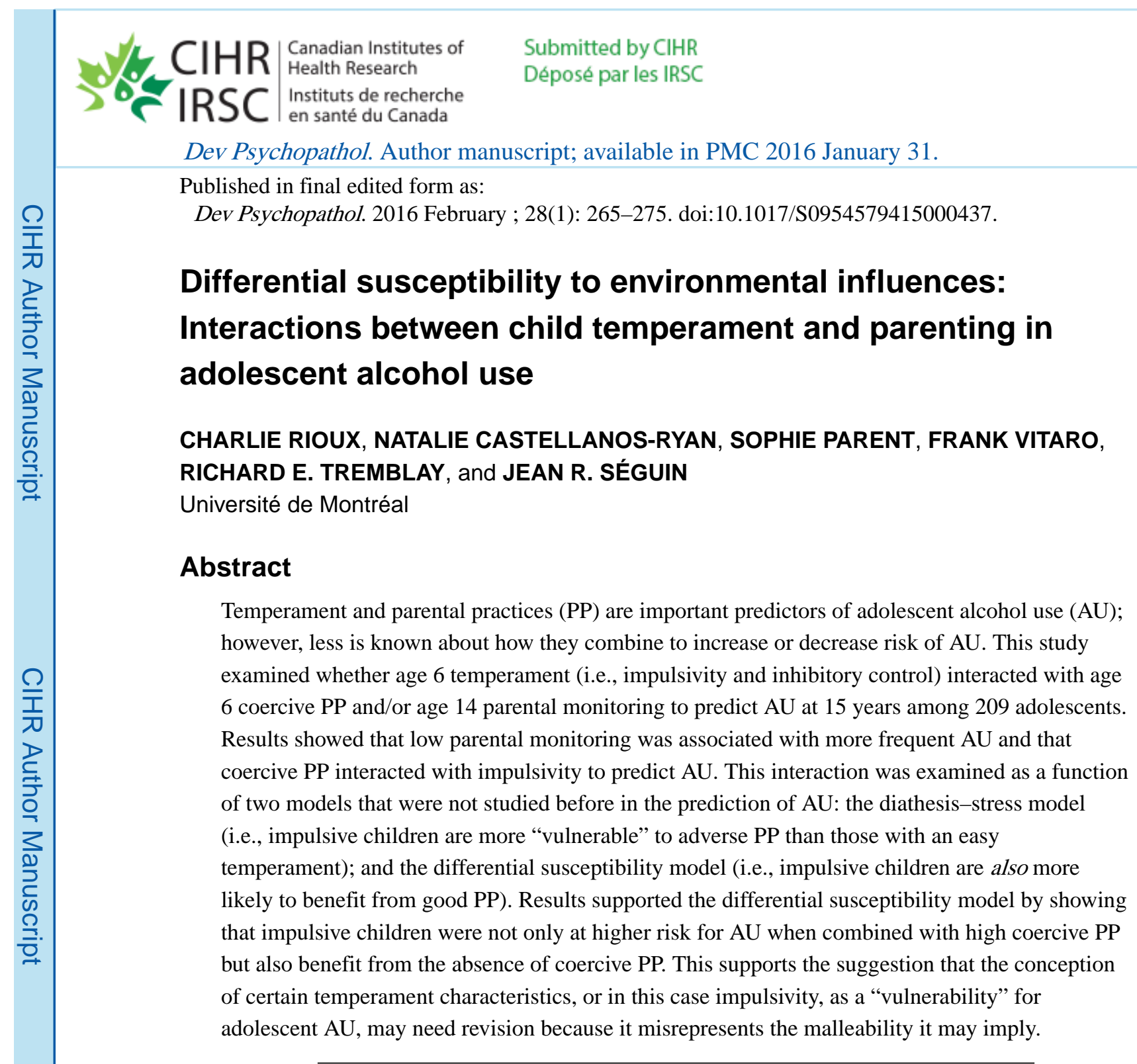

Adolescent alcohol use is a prevalent health and social problem (Institut de la statistique du Québec, 2009; Johnston, O'Malley, Bachman, \& Schulenberg, 2013) with several short- and long-term consequences (Newbury-Birch et al., 2009). Studies have found that temperament (Wennberg \& Bohman, 2002; Willem et al., 2011) and parental practices (Cablova, Pazderkova, \& Miovsky, 2014; Ryan, Jorm, \& Lubman, 2010) were associated with adolescent alcohol use and that they interacted to predict risk for alcohol use (Armstrong et al., 2013; Burk et al., 2011; Stice \& Gonzales, 1998). While previous research considered temperament as a vulnerability factor leading to higher alcohol use in the context of adverse environments, recent theoretical work suggests temperament could also be indicative of individuals' susceptibility to environmental factors such as parenting (Belsky \& Pluess, 2009, 2013): some temperamental characteristics would be both disadvantageous in adverse environments and advantageous in favorable environments. Thus, the purpose of this study is to examine the interaction between temperament and parenting variables in the prediction of

Address correspondence and reprint requests to: Natalie Castellanos-Ryan, École de Psychoéducation, Université de Montréal, Pavillon Marie-Victorin, 90 avenue Vincent-d'Indy, Outremont, H2V 2S9 QC, Canada; natalie.castellanos.ryan@umontreal.ca. 
adolescent alcohol use while considering theoretical models that could explain those interactions.

\section{Temperament and Alcohol Use}

Temperament refers to early emerging individual differences regarding reactivity, which refers to the speed and intensity of emotional arousal, attention, and motor activity (e.g., impulsivity, emotionality, and activity level), and self-regulation, which refers to the strategies that modify reactivity (e.g., inhibitory control and attentional control). These differences are relatively stable and have some genetic foundation (Rothbart \& Bates, 2006).

Research shows that several dimensions of temperament are related to alcohol use (Caspi, Moffitt, Newman, \& Silva, 1996; Colder \& Chassin, 1997; Giancola \& Mezzich, 2003; Hartman, Hopfer, Corley, Hewitt, \& Stallings, 2013; Tubman \& Windle, 1995; Wennberg \& Bohman, 2002; Willem et al., 2011; Windle, 1991). Of note, early inhibition has been associated with alcohol use (Caspi et al., 1996). Research shows that some inhibited children later develop high anxiety levels (Degnan, Almas, \& Fox, 2010; Degnan \& Fox, 2007) and other internalizing symptoms, which are in turn associated with alcohol use (Hussong, Jones, Stein, Baucom, \& Boeding, 2011; Saban \& Flisher, 2010), suggesting that those children could be using alcohol as a self-medicating strategy to reduce negative affect (Weinberger \& Bartholomew, 1996). Early impulsivity has also been shown to be associated with later alcohol use (Colder \& Chassin, 1997; Willem et al., 2011), through increased risk for antisocial behavior (Clark, 2005), an important risk factor for substance use (Conner \& Lochman, 2010; Swadi, 1999).

\section{Parental Practices and Alcohol Use}

Several dimensions of parental practices have been found to be associated with adolescent alcohol use and could interact with inhibition or impulsivity to predict alcohol use. Among those, parental monitoring has been repeatedly associated with alcohol use (e.g., Abar, Jackson, Colby, \& Barnett, 2014; Barnes, Reifman, Farrell, \& Dintcheff, 2000; Clark, Shamblen, Ringwalt, \& Hanley, 2012; DiClemente et al., 2001; Duncan, Duncan, Biglan, \& Ary, 1998; Kaynak et al., 2013; Steinberg, Fletcher, \& Darling, 1994; Tornay et al., 2013). A possible mechanism to explain this association is that poorly monitored youths tend to associate with more deviant peers (Ary, Duncan, Duncan, \& Hops, 1999; Lloyd \& Anthony, 2003; Pinchevsky et al., 2012), an important correlate of adolescent substance use (Leung, Toumbourou, \& Hemphill, 2014; Marschall-Lévesque, Castellanos-Ryan, Vitaro, \& Séguin, 2014).

Coercive parenting is another parenting variable that has been shown to predict adolescent alcohol use (Aquilino \& Supple, 2001; Barnes \& Farrell, 1992; Fergusson \& Lynskey, 1997) and is also related to externalizing problems (Burnette, Oshri, Lax, Richards, \& Ragbeer, 2012; Gartstein \& Fagot, 2003), which co-occur highly with substance use (CastellanosRyan \& Conrod, 2011; Krueger et al., 2002). Coercive parenting could lead to alcohol use by increasing conduct problems in childhood, which are associated with rejection from the 
normal peer group and academic failure, and would, in turn, increase the likelihood of adolescents joining a deviant peer group (Patterson, DeBaryshe, \& Ramsey, 1990).

\section{Temperament, Parenting, and Alcohol Use}

Although studies have found direct effects of both temperament and parenting on adolescent alcohol use, it has been suggested that an interaction between temperament and the environment (i.e., parenting), could lead to alcohol use as a result of their joint influence on proximal adolescent factors (e.g., academic competence and peer affiliation; Wills \& Dishion, 2004). Only three studies have focused on the interplay between temperament and parenting in the prediction of adolescent alcohol use, and how parental practices may exacerbate or dampen the risk conveyed by temperamental characteristics. The earliest study was cross-sectional and found that impulsivity at ages 12 and 13 years was positively associated with more frequent alcohol use, and this association was greater at low levels of paternal support (Stice \& Gonzales, 1998). The other two studies assessed the link between childhood predictors (temperament and parenting practices) and adolescent alcohol use in the same prospective cohort. The first one (Burk et al., 2011) found that boys scoring high on temperamental disinhibition at age 4 years had higher levels of alcohol use in Grade 10 only when exposed to low levels of authoritative parenting in childhood, which is characterized by clear rules and monitoring that still allowed child independence. The second study (Armstrong et al., 2013) found that girls and boys high in temperamental disinhibition at ages 3.5 and 4.5 years who were exposed to low authoritative parenting in childhood had higher levels of Grade 9 alcohol use. In contrast, authoritarian parenting, characterized by control, criticism, and punishment, predicted growth of alcohol use from Grade 9 to Grade 12. Boys and girls low in dis-inhibition at ages 3.5 and 4.5 years exposed to low authoritarian parenting showed a steeper increase in their alcohol use at the beginning of high school that then leveled off, while those exposed to high authoritarian parenting had less alcohol consumption initially but increased more rapidly by Grade 12 . Whereas boys high in disinhibition all had a steep increase in alcohol use from Grade 9 to Grade 12, authoritarian parenting may have had a protective effect on girls high in temperamental disinhibition, for whom the increase in alcohol consumption leveled off by Grade 12 .

\section{Personal Characteristics $\times$ Environment Interactions: Theoretical Models}

Most of the research on interactions between personal characteristics, such as temperament, and the environment, such as parenting, is based on the diathesis-stress model (Monroe \& Simons, 1991; Zuckerman, 1999), which posits that vulnerable individuals (e.g., impulsive or inhibited children) are more likely to be affected negatively by an environmental stressor. Thus, according to this theory, highly impulsive and inhibited children are "vulnerable" and would have higher levels of adolescent alcohol use than "resilient" children without those temperamental characteristics when exposed to adverse parental practices. This vulnerability is only observed in adverse environments; vulnerable and resilient children would develop similarly in the absence of adverse parental practices.

A more recent and complementary theory challenges this conception. The differential susceptibility model posits that, in addition to being affected adversely by negative 
environmental conditions, individuals with certain susceptibility factors may also benefit more from good environmental conditions or from the absence of adversity (Belsky, 2005; Belsky, Bakermans-Kranenburg, \& van IJzendoorn, 2007; Belsky \& Pluess, 2009, 2013; Ellis, Boyce, Belsky, Bakermans-Kranenburg, \& van IJzendoorn, 2011). This theory hypothesizes that the susceptibility factor would be rooted in a nervous system that is more "plastic and malleable" (Pluess \& Belsky, 2009, 2010). Thus, rather than being vulnerable to adverse environments, children with so-called difficult temperament characteristics could be "susceptible" to both negative and positive parental practices. Therefore, susceptible impulsive and inhibited children would have lower levels of alcohol use than nonimpulsive and noninhibited children when exposed to positive parental practices in addition to having higher levels of alcohol use when exposed to adverse parenting. Impulsivity and inhibition would no longer be conceived exclusively as risk factors; they would also hold the promise of greater benefits from positive environments.

These two models may be distinguished empirically by careful analyses of the patterns of statistical interaction. Statistical support for the diathesis-stress model comes from a pattern where an individual characteristic is related to an outcome and an ordinal (fan-shaped) interaction is found (Belsky et al., 2007). Support for the differential susceptibility model is demonstrated when a disordinal (crossover) interaction is found, with the slope of the association between the environmental factor and the outcome for the susceptible group being significantly different from zero and significantly steeper than the slope for the nonsusceptible group. Finally, the susceptibility factor should not be related to the environmental factor or to the outcome (Belsky et al., 2007; Belsky \& Pluess, 2009). Once these criteria have been met, two additional steps designed to test the significance of the crossover interaction have been proposed that go beyond simple appraisal of the plots (Roisman et al., 2012; Widaman et al., 2012). A model fitting test has recently been proposed to more directly compare interaction patterns representing "weak" and "strong" versions of the diathesis-stress and differential susceptibility models without requiring a significant statistical interaction, making this approach more liberal (Belsky, Pluess, \& Widaman, 2013).

The majority of previous studies examining interactions between temperament and parenting as well as other family factors in the prediction of adolescent alcohol use and other outcomes were conducted within a diathesis-stress frame of reference. However, recent studies found gene-environment interactions in the prediction of substance use that support the differential susceptibility model (Daw et al., 2013, 2014; Laucht et al., 2012; Park, Sher, Todorov, \& Heath, 2011). Furthermore, Belsky and Pluess $(2009,2013)$ reexamined prior published studies to determine the extent to which they supported the differential susceptibility model. Potential support for the model was found with temperament and family measures in the prediction of externalizing problems (Bradley \& Corwyn, 2008; Lengua, 2008; Leve, Kim, \& Pears, 2005; Pitzer, Jennen-Steinmetz, Esser, Schmidt, \& Laucht, 2011; Pluess \& Belsky, 2009; Poehlmann et al., 2012; Smeekens, Riksen-Walraven, \& van Bakel, 2007; van Aken, Junger, Verhoeven, van Aken, \& Dekovic, 2007), depression symptoms (Lengua, Wolchik, Sandler, \& West, 2000), attachment security (Velderman, Bakermans-Kranenburg, Juffer, \& van IJzendoorn, 2006), and other outcomes. It is possible 
that this may also be the case for adolescent alcohol use, which should be examined specifically and a priori.

\section{The Present Study}

The first objective of this study was to examine whether child temperament and parenting characteristics interact in the prediction of alcohol use at 15 years. It is hypothesized that high coercive parenting in early childhood and/or low parental monitoring in adolescence will be associated with a higher frequency of adolescent alcohol use for children high in impulsivity and/or low in inhibitory control. The second objective was to examine whether low coercive parenting and/or low parental monitoring will also be associated with a lower frequency of alcohol use for children high in impulsivity and/ or low in inhibitory control, which would support the differential susceptibility model.

\section{Method}

\section{Participants}

Participants for this study come from a longitudinal study aiming to better understand the social, psychological, and cognitive development of children in Québec. One thousand families from all socioeconomic backgrounds were randomly selected from urban areas in the Québec birth registry in 1996-1997 (Santé Québec, Jetté, Desrosiers, \& Tremblay, 1997), with 572 francophone (90\%) and anglophone (10\%) families participating at the first assessment when the children were 5 months old. This urban sample differed slightly from a larger population-based sample of Québec 5-month-old children born 2 years later (Tremblay et al., 2004). Parents in the urban sample were more likely to have finished high school (90\% vs. $84 \%$ ) or have postsecondary education (57\% vs. 50\%) compared to parents in the larger population. Mothers in the sample were also older than in the larger population at the birth of the participants ( 29.9 vs. 28.8 years). There were no differences between the urban and population samples regarding fathers' age (32.3 vs. 31.8 years) and proportion of family income under Can\$30,000 (26\% vs. 29\%).

The participants were followed annually. Due to attrition, loss to follow-up, and year-to-year variations in participation rates, 209 participants (52\% girls) participated at age 15 years for the present study. This final subsample did not differ significantly from the remainder of the urban sample on parenting at 6 years $(p=.41 ; n=363)$ and temperament at 6 years $(p=.10$; $n=273)$ as well as sex $(p=.80 ; n=572)$ and family income at 5 months $(p=.18 ; n=538)$. The University of Montreal, the Hôpital Louis Hippolyte Lafontaine, and the CHU SainteJustine Research Center ethics committees approved this project.

\section{Measures}

Temperament-Child temperament was assessed at 6 years using the Children's Behavior Questionnaire (Rothbart, Ahadi, Hershey, \& Fisher, 2001), rated by the mother using 7-point scales with ( $1=$ extremely inaccurate, $7=$ extremely accurate $)$. Two scales were used: six items on impulsivity (speed of response initiation; e.g., has a habit of jumping into an activity without much prior thought; $M=26.89, S D=5.58$; skewness $=-0.28$; kurtosis $=0.20$ ), and six items on inhibitory control (capacity to plan and to suppress inappropriate 
responses under instructions or in novel situations; e.g., when told that a place is dangerous, he/she goes there slowly and carefully; $M=30.28, S D=5.58$; skewness $=-0.39$; kurtosis = -0.16). The Cronbach as for both scales were 0.78 (Rothbart et al., 2001).

Parental practices-Coercive parenting was assessed at 6 years using questions based on the Parent Practices Scale (Strayhorn \& Weidman, 1988) and on the first cycle of the National Longitudinal Survey of Children and Youth (Statistics Canada, 1995). Mothers reported on seven questions (e.g., how often do you raise your voice, scold, or yell at him/ her?). Each item was rated on a 5-point scale $(1=$ never, 5 many times each day, or all the time), depending on the question asked $(M=14.99, S D=2.98$; skewness $=0.58$; kurtosis = 0.66). Cronbach a for this scale was 0.71 (Statistics Canada, 1998).

Parental monitoring was assessed by adolescent report when the participants were 14 years old with two items asking "Do your parents know where you are when you go out?" and "Do your parents know with whom you are when you go out?" Answers for these questions were given on a 5-point scale ranging from never to always $(M=3.37, S D=0.78$; skewness $=-0.89$; kurtosis $=-0.19$ ). These questions were sensitive in other studies (e.g., Brendgen, Vitaro, Tremblay, \& Lavoie, 2001; Haapasalo \& Tremblay, 1994).

Alcohol use-Adolescents reported on their substance use when they were 15 years old. Alcohol use frequency was assessed with a question based on the Québec Survey on Tobacco, Alcohol and Drug Use and Gambling in Secondary School Students (Institut de la statistique du Québec, 2007) and asking participants at what frequency they had consumed alcohol in the last 12 months. Answers for this question were given on a 7-point Likert scale ranging from $I$ have never used alcohol to every day $(M=2.27, S D=1.90$; skewness $=0.08$; kurtosis $=-1.30$ ).

\section{Data analyses}

In order to test main and interaction effects of age 6 and age 14 parental practices and age 6 temperament in the prediction of age 15 adolescent alcohol use, a series of linear regressions (path analysis) were conducted using Mplus version 7.0 (Muthén \& Muthén, 1998-2012) and following guidelines provided by Cohen, Maiersperger, Gower, and Turner (2003) and Frazier, Tix, and Barron (2004). We included sex, the two predictors (age 6 coercive parenting and age 14 parental monitoring) and the two moderators (age 6 impulsivity and inhibitory control) in the first model, and the interaction terms between the predictors and the moderators were included in the second model. All predictor and moderator variables were standardized before computing interaction terms and entering variables in the analysis. Full information maximum likelihood was used to account for missing data. Three-way interactions with sex were also tested and were not significant. When significant interactions were found, the effect of the predictor was plotted as a function of the moderator and followed by simple slope tests to determine the nature of the interaction.

To determine if the differential susceptibility model was supported, significant interactions were examined according to the four criteria previously mentioned. Following the examination of those criteria, additional steps have been proposed (Roisman et al., 2012), which include the identification of the regions of significance using the Johnson-Newman 
technique. While this method has been used in most recent studies examining the differential susceptibility model, it can lack power in small samples and when the environmental variable does not cover the entire range, from very enriched to very adverse (Belsky et al., 2014; Dick, 2011; Duncan \& Keller, 2011; Lei, Simons, Edmond, Simons, \& Cutrona, 2014). A new procedure that addresses these power issues was used in this study and can determine statistically if the interaction is disordinal (Widaman et al., 2012). With this procedure, the crossover point and its confidence interval are estimated: an interaction is disordinal and supports the differential susceptibility model when the confidence interval of the crossover point falls within the observed range of the predictor (i.e., parenting). If the crossover point is outside the observed range of the predictor, the interaction is ordinal and supports the diathesis-stress model.

\section{Results}

\section{Descriptive statistics}

Table 1 presents correlations between the variables that were used in regression analyses. There was a small correlation between sex and parental monitoring at 14 years, and between sex and inhibitory control at 6 years; girls reported more monitoring from their parents and had higher levels of inhibitory control. Inhibitory control at 6 years was mildly negatively correlated with impulsivity at 6 years. Coercive parenting at 6 years and parental monitoring at 14 years were mildly and negatively correlated with each other. Coercive parenting at 6 years was negatively associated with inhibitory control and positively correlated with impulsivity, both assessed at 6 years, while parental monitoring at 14 years was only associated positively with inhibitory control at 6 years. There were no correlations between alcohol use scores at 15 years and temperament scores at 6 years, but alcohol use frequency at 15 years was mildly negatively correlated with parental monitoring at 14 years.

As noted previously, the differential susceptibility model requires the predictor and moderator to be independent from each other. However, coercive parenting was mildly associated with both impulsivity and inhibitory control at age 6 . Because this could be due to shared method variance and could complicate the interpretation of interactions, coercive parenting was regressed on impulsivity and inhibitory control, and the residual coercive parenting score was used in the analyses to control for any correlation, as is often done in other studies testing the differential susceptibility model (Nederhof, Belsky, Ormel, \& Oldehinkel, 2012; Ramchandani, van IJzendoorn, \& Bakermans-Kranenburg, 2010). The findings did not change whether the original or residual score were used. The following results are from the analysis using the residual score.

\section{Main and interaction effects}

As shown in Table 2, only one significant main effect was found in the first step of the model. Low levels of parental monitoring at 14 years were associated with higher levels of alcohol use frequency at 15 years $\left(R^{2}=.10\right)$. One significant interaction effect was found in the second step of the analysis: an interaction between impulsivity and coercive parenting at 6 years positively predicted alcohol use frequency at 15 years $\left(\Delta R^{2}=.04\right)$. Simple slope analyses showed that the effect of coercive parenting at 6 years was significant when 
impulsivity at 6 years was high, but not when it was low (see Figure 1). Relative to children low in impulsivity, children high in impulsivity had both higher levels of alcohol use frequency at 15 years when exposed to high coercive parenting at 6 years and lower levels of alcohol use frequency at 15 years when exposed to low coercive parenting at 6 years.

\section{Support for the differential susceptibility model}

According to the plotted data and the simple slope tests, the interaction met criteria for the differential susceptibility model. It was a disordinal (crossover) interaction. The estimate for the crossover point $(C=-0.86, S E=0.14,95 \%$ confidence interval $=-1.13,-0.59)$, fell just below the standardized sample mean. In addition, the confidence intervals of the crossover point fell well within the observed standardized values of coercive parenting $(\min =-2.22$, $\max =2.64$ ). The slope for the children high in impulsivity at 6 years differed significantly from zero. The slope for the children high in impulsivity at 6 years was steeper than the slope for the children low in impulsivity, which was not significantly different from zero. Finally, impulsivity at 6 years was not related to alcohol use frequency at 15 years or to residuals of coercive parenting at 6 years. ${ }^{1}$

\section{Discussion}

The objectives of this study were twofold. The first objective was to determine if temperamental and parenting dimensions that predicted substance use through main effects in previous studies could interact to predict adolescent alcohol use. A second objective was to examine if such interactions could be interpreted according to a diathesis-stress or a differential susceptibility model. The main findings of this study first indicate that low parental monitoring in adolescence was associated with a higher frequency of alcohol use. Second, we found that not only did child impulsivity and coercive parenting interact to predict adolescent alcohol use but also that this interaction supports the differential susceptibility model. This suggests that, with regard to adolescent alcohol use, early impulsivity may be a key marker of plasticity, which confers risk under certain conditions and a clear advantage under other conditions.

\section{Joint contribution of temperament and parenting to adolescent alcohol use}

After examining whether childhood temperament (i.e., impulsivity and inhibitory control) interacted with parental practices (i.e., coercive parenting in childhood and monitoring in adolescence) in the prediction of adolescent alcohol use, we found that higher levels of age 6 impulsivity were associated with more frequent alcohol use at 15 years when children were also exposed to coercive parenting at 6 years. These findings are consistent with and extend those of other studies showing that impulsive temperament traits interacted with parental practices in the prediction of substance use. As reviewed above, interactions were found in the prediction of alcohol use with impulsivity and parental support (Stice \& Gonzales, 1998) as well as with temperamental disinhibition and authoritative parenting (Armstrong et al.,

\footnotetext{
${ }^{1}$ The differential susceptibility model was also tested in SPSS using the model fitting approach proposed by Belsky, Pluess, and Widaman (2013) and expectation-maximization single imputation for missing data. This method yielded similar results, confirming that a weak differential susceptibility model was a better fit for the interaction between impulsivity and coercive parenting, and that no other interactions were significant even when using this more liberal approach.
} 
2013; Burk et al., 2011). Interactions with impulsivity and coercive parenting were also found in the prediction of externalizing problems (Leve et al., 2005).

While we found that early childhood temperament and parenting could predict adolescent alcohol use, other variables could come into play across developmental periods. The interaction we observed between impulsivity and coercive parenting in childhood could lead to adolescent alcohol use through its contribution to other late childhood or early adolescent variables (Wills \& Dishion, 2004). Thus, future studies could investigate a mediated moderation model (Muller, Judd, \& Yzerbyt, 2005) where one could test whether the interaction between early impulsivity and coercive parenting is mediated by more proximal variables in adolescence that have been shown to predict adolescent alcohol use (e.g., peer affiliations; Leung et al., 2014; Marschall-Lévesque et al., 2014; and conduct problems; Castellanos-Ryan, Séguin, Vitaro, Parent, \& Tremblay, 2013; Clark, 2005).

Whereas coercive parenting and impulsivity at 6 years interacted to predict alcohol use at 15 years, coercive parenting did not interact with inhibitory control at 6 years. Several factors could account for this difference across temperament dimensions. First, although these two temperamental dimensions were mildly correlated, they are quite different in that impulsivity is a measure of reactivity and inhibitory control is a measure of self-regulation. Impulsivity represents spontaneous and quick reactions to the environment, whereas inhibitory control represents the conscious decision-making process involved in suppressing inappropriate dominant responses (Rothbart et al., 2001). Thus, in this sample, the tendency at 6 years to have quick spontaneous reactions seems more important in the prediction of early adolescent alcohol use than the absence of the conscious regulation of reactions when faced with exterior demands. Second, our hypothesis was based on reported links between early "inhibition" with substance use (Caspi et al., 1996; Hussong et al., 2011). However, by using the term inhibition, it is unclear to which of attentional, motivational, cognitive, and motor dimensions of inhibition these studies are referring (Nigg, 2000). In this study, we measured inhibitory control, a self-regulatory measure implicating decision making. It is possible that alcohol use is associated with other temperamental measures of "inhibition," such as measures that focus on the behavioral dimensions of inhibition. Future studies comparing different measures of inhibition could test this hypothesis.

A main effect of parental monitoring at 14 years was also found, showing that lower levels of monitoring at 14 years were associated with more frequent alcohol use at 15 years, which is consistent with the results of previous studies (e.g., Barnes et al., 2000; Clark et al., 2012; DiClemente et al., 2001; Duncan et al., 1998; Kaynak et al., 2013; Steinberg et al., 1994; Tornay et al., 2013). Although coercive parenting in childhood interacted with concurrent impulsivity in predicting adolescence alcohol use, the interactions of parental monitoring in adolescence with childhood impulsivity or inhibitory control did not predict alcohol use. This suggests that the interplay between parenting and temperament on adolescent alcohol may change across development, and that parental monitoring during adolescence may be beneficial to all adolescents in reducing risk for alcohol use. In contrast, that childhood temperament interacted with concurrent parental practices, but not with parenting in adolescence, could be explained methodologically, because reports were not only obtained from different informants but also measured different facets of parental practices. To 
determine whether this difference between these statistical interactions in childhood and adolescence was due to developmental or measurement differences, future studies could examine whether temperament measured in adolescence interacts with parenting in adolescence, examine the same parenting dimension in childhood and adolescence, or use the same informant for parenting in childhood and adolescence.

\section{Support for the theoretical models and implications}

The significant interaction between impulsivity and coercive parenting was examined to determine whether it supported the diathesis-stress model or the differential susceptibility model, a question that had not been tested in previous studies of temperament and parenting in the prediction of alcohol use. The interaction met the four key criteria for support of the differential susceptibility model. When exposed to low coercive parenting, children with higher levels of impulsivity at 6 years had less frequent alcohol use at 15 years than did children with low levels of impulsivity. Because this sample came from a normal urban population and the coercive parenting variable was normally distributed, a mean level of coercion represented the norm. Consequently, a low level of coercive parenting represented mothers that were particularly skillful at avoiding coercive strategies to supervise and socialize their child. In other words, it was a markedly low level of coercion from the mother that may have been beneficial for 6-year-old children high in impulsivity. Whereas impulsivity is mostly seen as a risk factor, the possibility that it could be an advantage is less commonly evoked. Under the skillful guidance of meaningful adults, impulsivity may confer an advantage because of the novelty-seeking aspect of this temperamental dimension, which could lead impulsive children to development opportunities. The spontaneity linked to impulsivity could bring these children to reveal themselves more readily to their noncoercive parents, leading to better parent-child communication, which is also important in the prediction of alcohol use (Ryan et al., 2010). Potential support for the differential susceptibility model was also previously found with impulsivity and coercive parenting in the prediction of externalizing problems but had not been tested a priori. Consistent with the interactions between impulsivity and coercive parenting found in the present study, a secondary analysis of an interaction between impulsivity and coercive parenting at age 5 in the prediction of girls' externalizing problems at 17 years (Leve et al., 2005) showed that this interaction supported the differential susceptibility model (Belsky \& Pluess, 2009). Because substance use is considered a subtype of externalizing problems (Castellanos-Ryan \& Conrod, 2011; Krueger et al., 2002), our results provide further support for the relevance of differential susceptibility in the case of substance use and, potentially, externalizing behaviors in general.

With further studies determining which individual characteristics and environmental conditions interact following a diathesis-stress or differential susceptibility pattern, the prevalent conception of individual vulnerability factors would need revising in order to include susceptibility/plasticity factors in developmental models. Both the diathesis-stress and the differential susceptibility models support targeting children for prevention based on their temperament characteristics. Both models show that adverse environments negatively affect children with a "difficult" temperament, making such combinations important targets of prevention and intervention programs. However, support for the differential susceptibility 
model for some early markers, such as impulsivity, could change the expectations regarding the outcomes of interventions. Parents, teachers, and practitioners might then develop higher, and more optimistic, expectations regarding the potential of children currently described as having a difficult temperament. Considering impulsivity as a risk factor, and children with this temperamental disposition as vulnerable, does not take into account the fact that their temperament could lead to aptitudes that go beyond the absence of a problem when combined with the right environment (Belsky \& Pluess, 2009; Bradley \& Corwyn, 2008; Pluess \& Belsky, 2009, 2010; Stright, Kelley, \& Gallagher, 2008).

Applying a differential susceptibility model clinically could have an impact not only in childhood but also later in life. There is also evidence of differential susceptibility in early adulthood (Aron \& Aron, 1997). Aron (2010) recommends personalizing clinical interventions in adulthood according to the degree of "sensitiveness" of the client, a concept closely related to the degree of susceptibility or openness to environmental influences. From a clinical perspective, Aron (2010) adds that while sensitive people may be more vulnerable, sensitivity is not only a liability but also may confer advantages. Thus, the main challenge for future studies of various temperamental characteristics is to determine which are vulnerability versus susceptibility factors and under which environmental conditions.

Experimental research is also needed. There are already various parenting interventions that can help reduce alcohol use and could be used in experimental studies. One recent metaanalysis shows that parenting programs based on social learning and cognitive-behavioral principles are the most effective in reducing problem behaviors in children and adolescents (Dretzke et al., 2009). Randomized controlled trials testing the effects of parenting and familial interventions in the prediction of both alcohol use (Beach, Brody, Lei, \& Philibert, 2010; Brody, Chen, \& Beach, 2013; Brody et al., 2014; Cleveland et al., in press) and externalizing problems (Albert et al., in press; Bakermans-Kranenburg, van IJzendoorn, Mesman, Alink, \& Juffer, 2008; van den Hoofdakker et al., 2012) have shown support for genetic differential susceptibility, with clear support for dopamine-related genes (see Bakermans-Kranenburg \& van IJzendoorn, 2015, for a meta-analytic review). Intervention studies using measures of temperament to classify children have also shown support for differential susceptibility in the prediction of attachment security (Cassidy, Woodhouse, Sherman, Stupica, \& Lejuez, 2011) and oppositional behavior (Scott \& O'Connor, 2012). Future research could test whether the impact of interventions targeting parental practices on substance use is moderated by the impulsivity levels of children and adolescents. To test the differential susceptibility model, these studies would have to randomize the parenting intervention, but temperament can be a fixed factor (Bakermans-Kranenburg \& van IJzendoorn, 2015). For example, coercive parents of children or early adolescents could be randomly assigned to a parenting intervention and control condition to then examine whether the intervention effects observed on substance use levels later in adolescence differ between the children low in impulsivity and those high in impulsivity. If the children high in impulsivity have better outcomes than those low in impulsivity, it would provide further support for the differential susceptibility model by demonstrating greater susceptibility to positive environments. 


\section{Strengths and limitations}

Only three studies before this one had examined the interactions between temperament and parental practices in the prediction of alcohol use (Armstrong et al., 2013; Burk et al., 2011; Stice \& Gonzales, 1998), with mostly Caucasian samples from the United States. Two of them were from the same laboratory and used the same sample, including measures from childhood to adolescence in a prospective design (Armstrong et al., 2013; Burk et al., 2011), a strength that the present study shares. Using a prospective design allowed the examination of the predictive relationships of temperament and parental practices from a developmental perspective. In addition, the present study extends previous research by (a) looking at parenting and temperamental variables that were shown to be related to alcohol use before but not studied in interaction with each other; (b) using a mostly French-speaking Canadian sample, which, although mostly Caucasian, adds to the generalizability of findings across North American samples; and (c) being the first study of temperament, parenting, and adolescent alcohol use outcomes that contrasts two important theoretical models of personenvironment interactions. Still, some limitations should be noted. The rate of substance use in the sample was lower than in the general adolescent population of Quebec. Sixty-six percent of the sample had used alcohol at least once by the age of 15 , while the rate in the general population at this age is $80 \%$ (Institut de la statistique du Québec, 2009). It should also be noted that the sample is urban, which limits the generalization of results. The alcohol use data was also obtained through self-report, which is susceptible to bias, notably social desirability. However, self-reports are often used and considered reliable in assessing substance use (Clark \& Winters, 2002). In addition, parenting was assessed with mothers only, and the effect might be different with fathers. Thus, it would be important to conduct research with father-reported parenting practices to see if the results are invariant across parents, though this recommendation must take into account the high rate of children who may not be raised by the same parents over time. Although sex was included as a covariate, other predictors of adolescent alcohol use (e.g., deviant peer affiliations, Leung et al., 2014; parental alcohol use, Sher, 1991; internalizing problems, O'Neil, Conner, \& Kendall, 2011; pubertal timing, Castellanos-Ryan, Parent, Vitaro, Tremblay, \& Séguin, 2013; Hummel, Shelton, Heron, Moore, \& van den Bree, 2013) were not included. Thus, this study did not show whether parental monitoring, coercive parenting, and impulsivity were still predictive of adolescent alcohol use when taking into account its more proximal predictors. However, because these variables were shown to predict alcohol use and externalizing problems in other studies (e.g., Abar et al., 2014; Leve et al., 2005), we could expect the results to be robust to other predictors. Finally, the participation rate from childhood to adolescence in this sample may limit generalizability to the originally sampled population, although attrition has an impact mostly on means and not on the associations between variables (Graham, 2009; Gustavson, von Soest, Karevold, \& Roysamb, 2012). Nonetheless, full information maximum likelihood was used to account for missing data, and as shown, the initial childhood and final adolescent samples were comparable on the main variables of interest.

\section{Conclusion}

Results of the present study showed that early temperament and parental practices interact in the prediction of alcohol use. Six-year-old children exposed to coercive parenting had more 
frequent alcohol use at 15 years when they were also impulsive at 6 years. Of greater significance, children high in impulsivity also had less frequent alcohol use than children low in impulsivity in the absence of coercive parenting, which supported the differential susceptibility model. Results also showed that low parental monitoring at 14 years was associated with a higher frequency of adolescent alcohol use at 15 years but did not interact with age 6 years temperament. With several studies on gene-environment interactions in the prediction of alcohol use now supporting the differential susceptibility model, more studies should examine which temperamental factors are vulnerability or susceptibility factors for alcohol use and with which environmental factors they interact. The differential susceptibility model could lead to changes in our conception of certain individual factors as vulnerability factors. In turn, this could change the expectations we have concerning what children with a difficult temperament can achieve and help determine which preventive interventions work better while considering individual temperamental differences.

\section{Acknowledgments}

This study was funded by the Canadian Institutes for Health Research via a scholarship (to C.R.), a fellowship (to J.R.S.), Grant MOP 44072 (to J.R.S.), and Grant MOP-97910 (to J.R.S., S.P., and F.V.); the Fonds de Recherche en Santé du Québec via the Réseau Santé Mentale du Québec (Québec Mental Health Network), via a scholarship (to C.R.), fellowships (to N.C.-R. and J.R.S.), Grant 981055 (to J.R.S. and R.E.T.), and Grant 991027 (to J.R.S.); the Fonds Québécois de la Recherche sur la Nature et les Technologies via Fellowship 149169 (to N.C.-R.); the Social Sciences and Humanities Research Council of Canada via Grant 839-2000-1008 (to R.E.T., F.V., J.R.S., and S.P.) and Grant 410-99-1048 (to S.P.); and the Fonds Québécois pour la recherche sur la Société et la Culture Grants 2002-RS-79238 and 2009-RG-124779. We are grateful to Charles-Édouard Giguère for data management and statistical analyses, and to our partner, the Institut de la Statistique du Québec. We thank all the parents and children for their generous participation in the study.

\section{References}

Abar CC, Jackson KM, Colby SM, Barnett NP. Common and unique parenting predictors of adolescent tobacco and alcohol use. Addictive Behaviors. 2014; 39:1528-1532. [PubMed: 24976458]

Albert W, Belsky D, Crowley D, Latendresse S, Aliev F, Riley B, et al. Can genetics predict response to complex behavioral interventions? Evidence from a genetic analysis of the Fast Track Randomized Control Trial. Journal of Policy Analysis and Management. (in press).

Aquilino WS, Supple AJ. Long-term effects of parenting practices during adolescence on well-being outcomes in young adulthood. Journal of Family Issues. 2001; 22:289-308.

Armstrong JM, Ruttle PL, Burk LR, Costanzo PR, Strauman TJ, Essex MJ. Early risk factors for alcohol use across high school and its covariation with deviant friends. Journal of Studies on Alcohol and Drugs. 2013; 74:746-756. [PubMed: 23948534]

Aron, EN. Psychotherapy and the highly sensitive person: Improving outcomes for that minority of people who are the majority of clients. New York: Routledge; 2010.

Aron EN, Aron A. Sensory-processing sensitivity and its relation to introversion and emotionality. Journal of Personality and Social Psychology. 1997; 73:345-368. [PubMed: 9248053]

Ary DV, Duncan TE, Duncan SC, Hops H. Adolescent problem behavior: The influence of parents and peers. Behaviour Research and Therapy. 1999; 37:217-230. [PubMed: 10087640]

Bakermans-Kranenburg MJ, van IJzendoorn MH. The hidden efficacy of interventions: Gene x environment experiments from a differential susceptibility perspective. Annual Review of Psychology. 2015; 66:381-409.

Bakermans-Kranenburg MJ, van IJzendoorn MH, Mesman J, Alink LRA, Juffer F. Effects of an attachment-based intervention on daily cortisol moderated by dopamine receptor D4: A randomized control trial on 1- to 3-year-olds screened for externalizing behavior. Development and Psychopathology. 2008; 20:805-820. [PubMed: 18606032] 
Barnes GM, Farrell MP. Parental support and control as predictors of adolescent drinking, delinquency, and related problem behaviors. Journal of Marriage and the Family. 1992; 54:763-776.

Barnes GM, Reifman AS, Farrell MP, Dintcheff BA. The effects of parenting on the development of adolescent alcohol misuse: A six-wave latent growth model. Journal of Marriage and the Family. 2000; 62:175-186.

Beach SRH, Brody GH, Lei MK, Philibert RA. Differential susceptibility to parenting among African American youths: Testing the DRD4 hypothesis. Journal of Family Psychology. 2010; 24:513 521. [PubMed: 20954761]

Belsky, J. Differential susceptibility to rearing influences: An evolutionary hypothesis and some evidence. In: Ellis, B., Bjorklund, D., editors. Origins of the social mind: Evolutionary psychology and child development. New York: Guilford Press; 2005. p. 139-163.

Belsky J, Bakermans-Kranenburg MJ, van IJzendoorn MH. For better and for worse: Differential susceptibility to environmental influences. Current Directions in Psychological Science. 2007; 16:300-304.

Belsky J, Newman DA, Widaman KF, Rodkin P, Pluess M, Fraley RC, et al. Differential susceptibility to effects of maternal sensitivity? A study of candidate plasticity genes. Development and Psychopathology. 2014 Advance online publication.

Belsky J, Pluess M. Beyond diathesis stress: Differential susceptibility to environmental influences. Psychological Bulletin. 2009; 135:885-908. [PubMed: 19883141]

Belsky J, Pluess M. Beyond risk, resilience, and dysregulation: Phenotypic plasticity and human development. Development and Psychopathology. 2013; 25:1243-1261. [PubMed: 24342838]

Belsky J, Pluess M, Widaman KF. Confirmatory and competitive evaluation of alternative geneenvironment interaction hypotheses. Journal of Child Psychology and Psychiatry. 2013; 54:11351143. [PubMed: 23617948]

Bradley RH, Corwyn RF. Infant temperament, parenting, and externalizing behavior in first grade: A test of the differential susceptibility hypothesis. Journal of Child Psychology and Psychiatry. 2008; 49:124-131. [PubMed: 18211274]

Brendgen M, Vitaro F, Tremblay RE, Lavoie F. Reactive and proactive aggression: Predictions to physical violence in different contexts and moderating effects of parental monitoring and caregiving behavior. Journal of Abnormal Child Psychology. 2001; 29:293-304. [PubMed: 11523835]

Brody GH, Chen YF, Beach SRH. Differential susceptibility to prevention: GABAergic, dopaminergic, and multilocus effects. Journal of Child Psychology and Psychiatry. 2013; 54:863-871. [PubMed: 23294086]

Brody GH, Chen YF, Beach SRH, Kogan SM, Yu T, DiClemente RJ, et al. Differential sensitivity to prevention programming: A dopaminergic polymorphism-enhanced prevention effect on protective parenting and adolescent substance use. Health Psychology. 2014; 33:182-191. [PubMed: 23379386]

Burk LR, Armstrong JM, Goldsmith HH, Klein MH, Strauman TJ, Costanzo P, et al. Sex, temperament, and family context: How the interaction of early factors differentially predict adolescent alcohol use and are mediated by proximal adolescent factors. Psychology of Addictive Behaviors. 2011; 25:1-15. [PubMed: 21443307]

Burnette ML, Oshri A, Lax R, Richards D, Ragbeer SN. Pathways from harsh parenting to adolescent antisocial behavior: A multidomain test of gender moderation. Development and Psychopathology. 2012; 24:857-870. [PubMed: 22781859]

Cablova L, Pazderkova K, Miovsky M. Parenting styles and alcohol use among children and adolescents: A systematic review. Drugs_Education Prevention and Policy. 2014; 21:1-13.

Caspi A, Moffitt TE, Newman DL, Silva PA. Behavioral observations at age 3 years predict adult psychiatric disorders-Longitudinal evidence from a birth cohort. Archives of General Psychiatry. 1996; 53:1033-1039. [PubMed: 8911226]

Cassidy J, Woodhouse SS, Sherman LJ, Stupica B, Lejuez CW. Enhancing infant attachment security: An examination of treatment efficacy and differential susceptibility. Development and Psychopathology. 2011; 23:131-148. [PubMed: 21262044] 
Castellanos-Ryan N, Conrod PJ. Personality correlates of the common and unique variance across conduct disorder and substance misuse symptoms in adolescence. Journal of Abnormal Child Psychology. 2011; 39:563-576. [PubMed: 21181434]

Castellanos-Ryan N, Parent S, Vitaro F, Tremblay RE, Séguin JR. Pubertal development, personality and substance use: A 10-year longitudinal study from childhood to adolescence. Journal of Abnormal Psychology. 2013; 122:782-796. [PubMed: 24016016]

Castellanos-Ryan N, Séguin JR, Vitaro F, Parent S, Tremblay RE. Impact of a 2-year multimodal intervention for disruptive 6-year-olds on substance use in adolescence: Randomised controlled trial. British Journal of Psychiatry. 2013; 203:188-195. [PubMed: 23929441]

Clark DB, Winters KC. Measuring risks and outcomes in substance use disorders prevention research. Journal of Consulting and Clinical Psychology. 2002; 70:1207-1223. [PubMed: 12472298]

Clark HK, Shamblen SR, Ringwalt CL, Hanley S. Predicting high risk adolescents' substance use over time: The role of parental monitoring. Journal of Primary Prevention. 2012; 33:67-77. [PubMed: 22370765]

Clark LA. Temperament as a unifying basis for personality and psychopathology. Journal of Abnormal Psychology. 2005; 114:505-521. [PubMed: 16351374]

Cleveland H, Schlomer S, Vandenbergh D, Feinberg M, Greenberg M, Spoth R, et al. Influences of interventions, parenting, and the dopamine receptor D4 gene on alcohol use in early adolescence. Development and Psychopathology. (in press).

Cohen WB, Maiersperger TK, Gower ST, Turner DP. An improved strategy for regression of biophysical variables and Landsat ETM+ data. Remote Sensing of Environment. 2003; 84:561571.

Colder CR, Chassin L. Affectivity and impulsivity: Temperament risk for adolescent alcohol involvement. Psychology of Addictive Behaviors. 1997; 11:83-97.

Conner BT, Lochman JE. Comorbid conduct disorder and substance use disorders. Clinical Psychology—Science and Practice. 2010; 17:337-349.

Daw J, Boardman JD, Peterson R, Smolen A, Haberstick BC, Ehringer MA, et al. The interactive effect of neighborhood peer cigarette use and 5HTTLPR genotype on individual cigarette use. Addictive Behaviors. 2014; 39:1804-1810. [PubMed: 25127196]

Daw J, Shanahan M, Harris KM, Smolen A, Haberstick B, Boardman JD. Genetic sensitivity to peer behaviors: 5HTTLPR, smoking, and alcohol consumption. Journal of Health and Social Behavior. 2013; 54:92-108. [PubMed: 23292504]

Degnan KA, Almas AN, Fox NA. Temperament and the environment in the etiology of childhood anxiety. Journal of Child Psychology and Psychiatry. 2010; 51:497-517. [PubMed: 20158575]

Degnan KA, Fox NA. Behavioral inhibition and anxiety disorders: Multiple levels of a resilience process. Development and Psychopathology. 2007; 19:729-746. [PubMed: 17705900]

Dick DM. Gene-environment interaction in psychological traits and disorders. Annual Review of Clinical Psychology. 2011; 7:383-409.

DiClemente RJ, Wingood GM, Crosby R, Sionean C, Cobb BK, Harrington K, et al. Parental monitoring: Association with adolescents' risk behaviors. Pediatrics. 2001; 107:1363-1368. [PubMed: 11389258]

Dretzke J, Davenport C, Frew E, Barlow J, Stewart-Brown S, Bayliss S, et al. The clinical effectiveness of different parenting programmes for children with conduct problems: A systematic review of randomised controlled trials. Child and Adolescent Psychiatry and Mental Health. 2009; 3:7. [PubMed: 19261188]

Duncan LE, Keller MC. A critical review of the first 10 years of candidate gene-by-environment interaction research in psychiatry. American Journal of Psychiatry. 2011; 168:1041-1049. [PubMed: 21890791]

Duncan SC, Duncan TE, Biglan A, Ary D. Contributions of the social context to the development of adolescent substance use: A multivariate latent growth modeling approach. Drug and Alcohol Dependence. 1998; 50:57-71. [PubMed: 9589273]

Ellis BJ, Boyce WT, Belsky J, Bakermans-Kranenburg MJ, van IJzendoorn MH. Differential susceptibility to the environment: An evolutionary-neurodevelopmental theory. Development and Psychopathology. 2011; 23:7-28. [PubMed: 21262036] 
Fergusson DM, Lynskey MT. Physical punishment/maltreatment during childhood and adjustment in young adulthood. Child Abuse \& Neglect. 1997; 21:617-630. [PubMed: 9238545]

Frazier PA, Tix AP, Barron KE. Testing moderator and mediator effects in counseling psychology research. Journal of Counseling Psychology. 2004; 51:115-134.

Gartstein MA, Fagot BI. Parental depression, parenting and family adjustment, and child effortful control: Explaining externalizing behaviors for preschool children. Journal of Applied Developmental Psychology. 2003; 24:143-177.

Giancola PR, Mezzich AC. Executive functioning, temperament, and drug use involvement in adolescent females with a substance use disorder. Journal of Child Psychology and Psychiatry. 2003; 44:857-866. [PubMed: 12959494]

Graham JW. Missing data analysis: Making it work in the real world. Annual Review of Psychology. 2009; 60:549-576.

Gustavson K, von Soest T, Karevold E, Roysamb E. Attrition and generalizability in longitudinal studies: Findings from a 15-year population-based study and a Monte Carlo simulation study. BMC Public Health. 2012; 12:918-928. [PubMed: 23107281]

Haapasalo J, Tremblay RE. Physically agressive boys from ages 6 to 12: Family background, parenting behavior, and prediction of delinquency. Journal of Consulting and Clinical Psychology. 1994; 62:1044-1052. [PubMed: 7806713]

Hartman C, Hopfer C, Corley R, Hewitt J, Stallings M. Using Cloninger's temperament scales to predict substance-related behaviors in adolescents: A prospective longitudinal study. American Journal on Addictions. 2013; 22:246-251. [PubMed: 23617866]

Hummel A, Shelton KH, Heron J, Moore L, van den Bree MBM. A systematic review of the relationships between family functioning, pubertal timing and adolescent substance use. Addiction. 2013; 108:487-496. [PubMed: 23163243]

Hussong AM, Jones DJ, Stein GL, Baucom DH, Boeding S. An internalizing pathway to alcohol use and disorder. Psychology of Addictive Behaviors. 2011; 25:390-404. [PubMed: 21823762]

Institut de la statistique du Québec. Enquête québécoise sur le tabac, l'alcool, la drogue et le jeu chez les élèves du secondaire, 2006. Sainte-Foy, QC: Publications du Québec; 2007.

Institut de la statistique du Québec. Enquête québécoise sur le tabac, l'alcool, la drogue et le jeu chez les élèves du secondaire, 2008. Sainte-Foy, QC: Publications du Québec; 2009.

Johnston, LD., O’Malley, PM., Bachman, JG., Schulenberg, JE. Monitoring the Future national findings on drug use: 2012 overview, key findings on adolescent drug use. Ann Arbor, MI: University of Michigan, Institute for Social Research; 2013.

Kaynak O, Meyers K, Caldeira KM, Vincent KB, Winters KC, Arria AM. Relationships among parental monitoring and sensation seeking on the development of substance use disorder among college students. Addictive Behaviors. 2013; 38:1457-1463. [PubMed: 23017733]

Krueger RF, Hicks BM, Patrick CJ, Carlson SR, Iacono WG, McGue M. Etiologic connections among substance dependence, antisocial behavior, and personality: Modeling the externalizing spectrum. Journal of Abnormal Psychology. 2002; 111:411-424. [PubMed: 12150417]

Laucht M, Blomeyer D, Buchmann AF, Treutlein J, Schmidt MH, Esser G, et al. Catechol-omethyltransferase Val158Met genotype, parenting practices and adolescent alcohol use: Testing the differential susceptibility hypothesis. Journal of Child Psychology and Psychiatry. 2012; 53:351-359. [PubMed: 21501166]

Lei MK, Simons RL, Edmond MB, Simons LG, Cutrona CE. The effect of neighborhood disadvantage, social ties, and genetic variation on the antisocial behavior of African American women: A multilevel analysis. Development and Psychopathology. 2014; 26:1113-1128. [PubMed: 24713449]

Lengua LJ. Anxiousness, frustration, and effortful control as moderators of the relation between parenting and adjustment in middle-childhood. Social Development. 2008; 17:554-577.

Lengua LJ, Wolchik SA, Sandler IN, West SG. The additive and interactive effects of parenting and temperament in predicting adjustment problems of children of divorce. Journal of Clinical Child Psychology. 2000; 29:232-244. [PubMed: 10802832] 
Leung RK, Toumbourou JW, Hemphill SA. The effect of peer influence and selection processes on adolescent alcohol use: A systematic review of longitudinal studies. Health Psychology Review. 2014; 8:426-457. [PubMed: 25211209]

Leve LD, Kim HK, Pears KC. Childhood temperament and family environment as predictors of internalizing and externalizing trajectories from ages 5 to 17. Journal of Abnormal Child Psychology. 2005; 33:505-520. [PubMed: 16195947]

Lloyd J, Anthony J. Hanging out with the wrong crowd: How much difference can parents make in an urban environment? Journal of Urban Health. 2003; 80:383-399. [PubMed: 12930878]

Marschall-Lévesque S, Castellanos-Ryan N, Vitaro F, Séguin JR. Moderators of the association between peer and target adolescent substance use. Addictive Behaviors. 2014; 39:48-70. [PubMed: 24183303]

Monroe SM, Simons AD. Diathesis-stress theories in the context of life stress research: Implications for the depressive disorders. Psychological Bulletin. 1991; 110:406-425. [PubMed: 1758917]

Muller D, Judd CM, Yzerbyt VY. When moderation is mediated and mediation is moderated. Journal of Personality and Social Psychology. 2005; 89:852-863. [PubMed: 16393020]

Muthén, LK., Muthén, BO. MPlus user's guide. 7. Los Angeles, CA: Author; 1998-2012.

Nederhof E, Belsky J, Ormel J, Oldehinkel AJ. Effects of divorce on Dutch boys' and girls' externalizing behavior in GenexEnvironment perspective: Diathesis-stress or differential susceptibility in the Dutch Tracking Adolescents' Individual Lives Survey study? Development and Psychopathology. 2012; 24:929-939. [PubMed: 22781863]

Newbury-Birch, D., Walker, J., Leah, A., Beyer, F., Brown, N., Jackson, K., et al. Impact of alcohol consumption on young people: A systematic review of published reviews. Newcastle: Newcastle University, Department for Children, Schools and Families; 2009. (Research Report DCSFRR067)

Nigg JT. On inhibition/disinhibition in developmental psychopathology: Views from cognitive and personality psychology and a working inhibition taxonomy. Psychological Bulletin. 2000; 126:220-246. [PubMed: 10748641]

O'Neil KA, Conner BT, Kendall PC. Internalizing disorders and substance use disorders in youth: Comorbidity, risk, temporal order, and implications for intervention. Clinical Psychology Review. 2011; 31:104-112. [PubMed: 20817371]

Park A, Sher KJ, Todorov AA, Heath AC. Interaction between the DRD4 VNTR polymorphism and proximal and distal environments in alcohol dependence during emerging and young adulthood. Journal of Abnormal Psychology. 2011; 120:585-595. [PubMed: 21381802]

Patterson GR, DeBaryshe B, Ramsey E. A developmental perspective on antisocial behavior. American Psychologist. 1990; 44:329-335.

Pinchevsky G, Arria A, Caldeira K, Garnier-Dykstra L, Vincent K, O’Grady K. Marijuana exposure opportunity and initiation during college: Parent and peer influences. Prevention Science. 2012; 13:43-54. [PubMed: 21870157]

Pitzer M, Jennen-Steinmetz C, Esser G, Schmidt MH, Laucht M. Differential susceptibility to environmental influences: The role of early temperament and parenting in the development of externalizing problems. Comprehensive Psychiatry. 2011; 52:650-658. [PubMed: 21215964]

Pluess M, Belsky J. Differential susceptibility to rearing experience: The case of childcare. Journal of Child Psychology and Psychiatry. 2009; 50:396-404. [PubMed: 19175816]

Pluess M, Belsky J. Differential susceptibility to parenting and quality child care. Developmental Psychology. 2010; 46:379-390. [PubMed: 20210497]

Poehlmann J, Hane A, Burnson C, Maleck S, Hamburger E, Shah PE. Preterm infants who are prone to distress: Differential effects of parenting on 36-month behavioral and cognitive outcomes. Journal of Child Psychology and Psychiatry. 2012; 53:1018-1025. [PubMed: 22582942]

Ramchandani PG, van IJzendoorn M, Bakermans-Kranenburg MJ. Differential susceptibility to fathers' care and involvement: The moderating effect of infant reactivity. Family Science. 2010; 1:93-101. [PubMed: 22073318]

Roisman GI, Newman DA, Fraley RC, Haltigan JD, Groh AM, Haydon KC. Distinguishing differential susceptibility from diathesis-stress: Recommendations for evaluating interaction effects. Development and Psychopathology. 2012; 24:389-409. [PubMed: 22559121] 
Rothbart MK, Ahadi SA, Hershey KL, Fisher P. Investigations of temperament at three to seven years: The children's behavior questionnaire. Child Development. 2001; 72:1394-1408. [PubMed: 11699677]

Rothbart, MK., Bates, JE. Temperament. In: Eisenberg, N., editor. Handbook of child psychology: Vol. 3. Social, emotional, and personality development. 6. Hoboken, NJ: Wiley; 2006.

Ryan SM, Jorm AF, Lubman DI. Parenting factors associated with reduced adolescent alcohol use: A systematic review of longitudinal studies. Australian and New Zealand Journal of Psychiatry. 2010; 44:774-783. [PubMed: 20815663]

Saban A, Flisher AJ. The association between psychopathology and substance use in young people: A review of the literature. Journal of Psychoactive Drugs. 2010; 42:37-47. [PubMed: 20464805]

Québec, Santé, Jetté, M., Desrosiers, H., Tremblay, RE. Rapport préliminaire de l'Étude longitudinale du développement des enfants du Québec (ÉLDEQ). Montréal: Gouvernement du Québec, Ministère de la Santé et des Services Sociaux; 1997. "En 2001. . j' aurai 5 ans!” Enquête auprès des bébés de 5 mois.

Scott S, O’Connor TG. An experimental test of differential susceptibility to parenting among emotionally-dysregulated children in a randomized controlled trial for oppositional behavior. Journal of Child Psychology and Psychiatry. 2012; 53:1184-1193. [PubMed: 22881827]

Sher, KJ. Children of alcoholics: A critical appraisal of theory and research. Chicago: University of Chicago Press; 1991.

Smeekens S, Riksen-Walraven JM, van Bakel HJA. Multiple determinants of externalizing behavior in 5-year-olds: A longitudinal model. Journal of Abnormal Child Psychology. 2007; 35:347-361. [PubMed: 17243016]

Statistics Canada. National Longitudinal Survey of Children: Survey Instruments for 1994-95, Data Collection, Cycle 1. Ottawa, ON: Author; 1995. (89F0077XIE)

Statistics Canada. National Longitudinal Survey of Children and Youth, Cycle 2-Microdata User Guide. Ottawa, ON: Author; 1998. Content and validation of NLSCY data.

Steinberg L, Fletcher A, Darling N. Parental monitoring and peer influences on adolescent substance use. Pediatrics. 1994; 93:1060-1064. [PubMed: 8197008]

Stice E, Gonzales N. Adolescent temperament moderates the relation of parenting to antisocial behavior and substance use. Journal of Adolescent Research. 1998; 13:5-31.

Strayhorn JM, Weidman CS. A parent practices scale and its relation to parent and child mental health. Journal of the American Academy of Child \& Adolescent Psychiatry. 1988; 27:613-618. [PubMed: 3182627]

Stright AD, Kelley K, Gallagher KC. Infant temperament moderates relations between maternal parenting in early childhood and children's adjustment in first grade. Child Development. 2008; 79:186-200. [PubMed: 18269517]

Swadi H. Individual risk factors for adolescent substance use. Drug and Alcohol Dependence. 1999; 55:209-224. [PubMed: 10428362]

Tornay L, Michaud PA, Gmel G, Wilson ML, Berchtold A, Suris JC. Parental monitoring: A way to decrease substance use among Swiss adolescents? European Journal of Pediatrics. 2013; 172:1229-1234. [PubMed: 23661237]

Tremblay RE, Nagin DS, Seguin JR, Zoccolillo M, Zelazo PD, Boivin M, et al. Physical aggression during early childhood: Trajectories and predictors. Pediatrics. 2004; 114:E43-E50. [PubMed: 15231972]

Tubman JG, Windle M. Continuity of difficult temperament in adolescence-Relations with depression, life events, family support, and substance use across a one-year period. Journal of Youth and Adolescence. 1995; 24:133-153.

van Aken C, Junger M, Verhoeven M, van Aken MAG, Dekovic M. The interactive effects of temperament and maternal parenting on toddlers externalizing behaviours. Infant and Child Development. 2007; 16:553-572.

van den Hoofdakker BJ, Nauta MH, Dijck-Brouwer DAJ, van der Veen-Mulders L, Sytema S, Emmelkamp PMG, et al. Dopamine transporter gene moderates response to behavioral parent training in children with ADHD: A pilot study. Developmental Psychology. 2012; 48:567-574. [PubMed: 22182296] 
Velderman MK, Bakermans-Kranenburg MJ, Juffer F, van IJzendoorn MH. Effects of attachmentbased interventions on maternal sensitivity and infant attachment: Differential susceptibility of highly reactive infants. Journal of Family Psychology. 2006; 20:266-274. [PubMed: 16756402]

Weinberger DA, Bartholomew K. Social-emotional adjustment and patterns of alcohol use among young adults. Journal of Personality. 1996; 64:495-527. [PubMed: 8656325]

Wennberg P, Bohman M. Childhood temperament and adult alcohol habits-A prospective longitudinal study from age 4 to age 36. Addictive Behaviors. 2002; 27:63-74. [PubMed: 11800225]

Widaman KF, Helm JL, Castro-Schilo L, Pluess M, Stallings MC, Belsky J. Distinguishing ordinal and disordinal interactions. Psychological Methods. 2012; 17:615-622. [PubMed: 22984788]

Willem L, Bijttebier P, Claes L, Sools J, Vandenbussche I, Nigg JT. Temperamental characteristics of adolescents with substance abuse and/or dependence: A case-control study. Personality and Individual Differences. 2011; 50:1094-1098.

Wills TA, Dishion TJ. Temperament and adolescent substance use: A transactional analysis of emerging self-control. Journal of Clinical Child and Adolescent Psychology. 2004; 33:69-81. [PubMed: 15028542]

Windle M. The difficult temperament in adolescence: Associations with substance use, family support, and problem behaviors. Journal of Clinical Psychology. 1991; 47:310-315. [PubMed: 2030139]

Zuckerman, M. Vulnerability to psychopathology: A biosocial model. Washington, DC: American Psychological Association; 1999. 


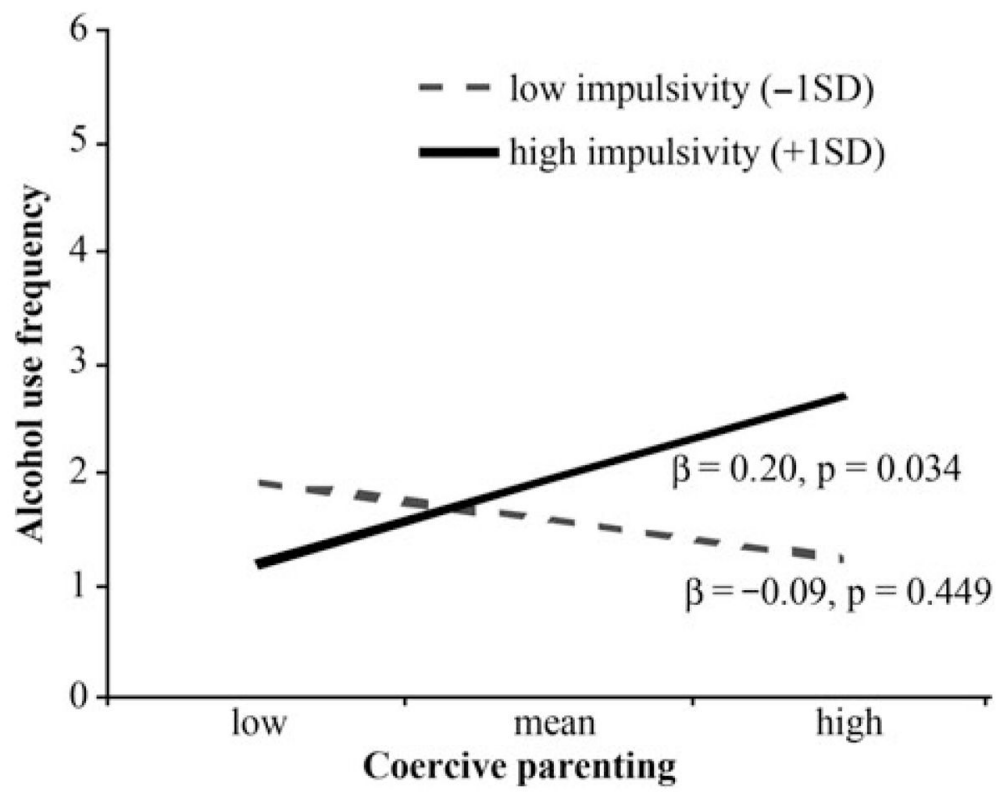

Figure 1.

Age 6 coercive parenting by impulsivity interaction predicting adolescent alcohol use frequency at 15 years. Sample size: low impulsivity (below $-1 S D$ ) $=37$, mean impulsivity (between $-1 S D$ and $+1 S D)=101$, and high impulsivity $($ above $+1 S D)=32$. 


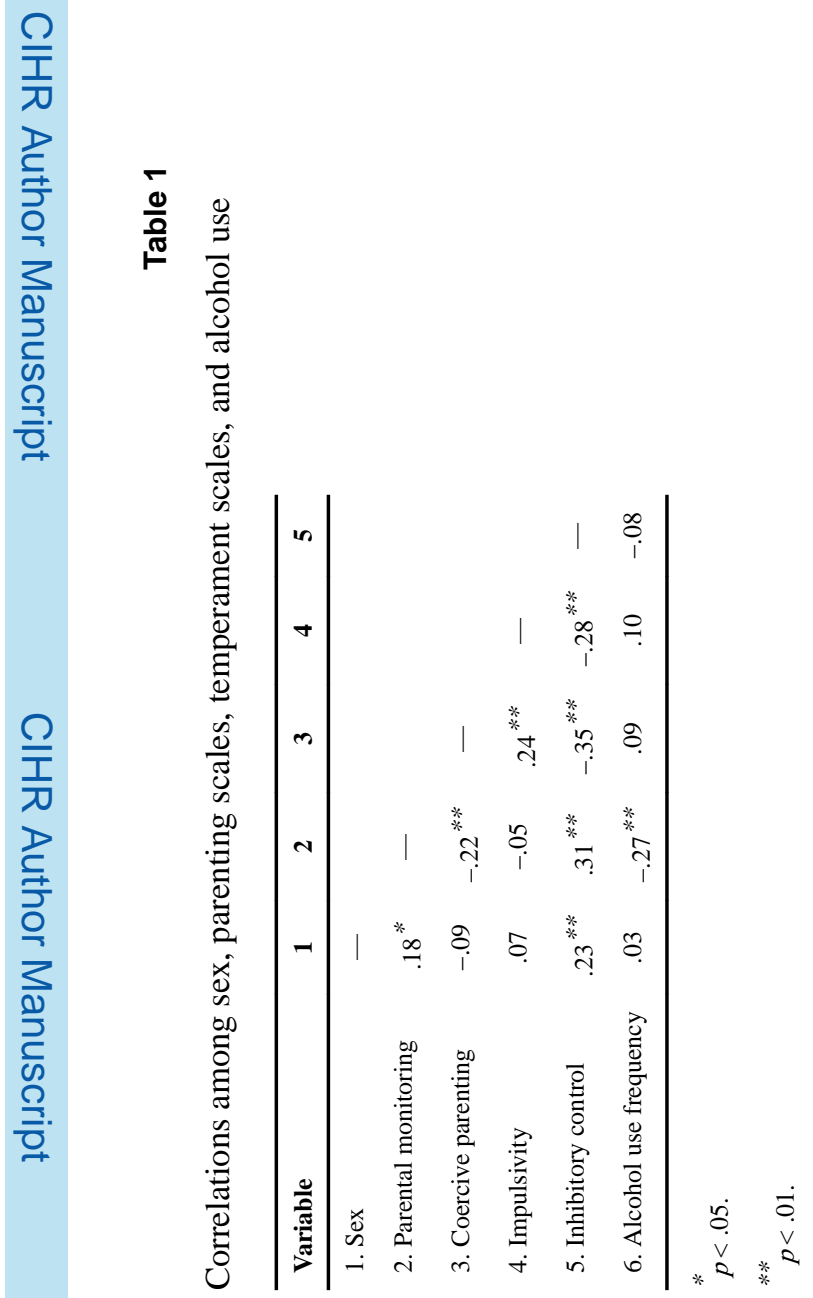




\section{Table 2}

Main and interaction effects of temperament at 6 years, coercive parenting at 6 years, and parental monitoring at 14 years on alcohol use frequency at 15 years

\begin{tabular}{lccc}
\hline & \multicolumn{3}{c}{ Alcohol Use Frequency } \\
\cline { 2 - 4 } & \multicolumn{1}{c}{$\boldsymbol{B}$} & $\boldsymbol{S} \boldsymbol{E}$ & $\boldsymbol{\beta}$ \\
\hline Main Effects (Model 1) & & \\
\hline Sex & 0.30 & 0.26 & 0.08 \\
Impulsivity & 0.15 & 0.16 & 0.08 \\
Inhibitory control & 0.05 & 0.18 & 0.03 \\
Coercive parenting & 0.15 & 0.15 & 0.08 \\
Parental monitoring & $-0.55^{* * *}$ & 0.15 & -0.29 \\
\hline \multirow{2}{*}{ Interaction Effects (Model 2$)$} & & \\
\hline Sex & 0.26 & 0.26 & 0.07 \\
Impulsivity & 0.05 & 0.82 & 0.03 \\
Inhibitory control & -0.74 & 0.80 & -0.40 \\
Coercive parenting & 0.10 & 0.17 & 0.05 \\
Parental monitoring & $-0.68^{* * *}$ & 0.22 & -0.26 \\
Impulsivity $\times$ Coercive Parenting & $0.28^{*}$ & 0.14 & 0.16 \\
Impulsivity $\times$ Parental Monitoring & 0.04 & 0.24 & 0.07 \\
Inhibitory Control $\times$ Coercive Parenting & 0.28 & 0.19 & 0.15 \\
Inhibitory Control $\times$ Parental Monitoring & 0.25 & 0.24 & 0.44 \\
\hline
\end{tabular}

Note: Model fit: Model 1: $\chi^{2}=1.281, d f=1$; comparative fit index $=0.978$; root mean square error of approximation $=0.037$; standardized root mean square residual $=0.019$. Model $2: \chi^{2}=1.278, d f=1$; comparative fit index $=0.980$; root mean square error of approximation $=0.036$; standardized root mean square residual $=0.017$.

${ }^{*}<.05$

** $p<.01$.

**** $p<.001$. 